\title{
THE HIBISCUS PANDURIFORMIS COMPLEX (MALVACEAE) IN AUSTRALIA
}

\author{
L.S. JUSWARA ${ }^{1} \&$ L.A. CRAVEN ${ }^{2}$
}

\begin{abstract}
SUMMARY
The Hibiscus panduriformis Burm.f. species complex in Australia is revised. Six species are recognised, of which one is the widespread $H$. panduriformis; one, $H$. austrinus, is based upon $H$. panduriformis var. australis; and four represent new species, H. apodus, H. calcicola, H. fluvialis, and H. multilobatus. A new variety is recognised in H. austrinus, namely var. occidentalis. Distribution maps are provided for all taxa and an exsiccatae list is included.
\end{abstract}

Key words: Hibiscus, Malvaceae, Australia, key, taxonomy.

\section{INTRODUCTION}

Hibiscus panduriformis Burm.f. was described in 1768 by Burman (1768). Burman's material apparently originated from the Indian-Malesian region (Merrill, 1921; Stafleu, 1971). No authentic specimens are known to exist and the description and characterisation of the species by Burman are rather poor but, despite this, the identity of the plant to which Burman was referring is clear (Van Borssum Waalkes, 1966).

In his revision of Hibiscus, Hochreutiner (1900) treated H. panduriformis as having three varieties: var. tubulosus (Cav.) Hochr. (nom. illeg. $=H$. panduriformis), var. senegalensis Hochr., and var. australis Hochr. Hochreutiner (1900) gave the distribution of the varieties as: var. panduriformis: tropical Africa, India and Malaya; var. australis: Australia; var. senegalensis: tropical Africa, but his infraspecific taxonomy for $H$. panduriformis has not been accepted by all subsequent authors. Exell (1961) reported that there was variation within this species in Africa and noted that the stems might be tomentose or hirsute and the flowers pubescent or glabrous. However, Exell could not find combinations of these features that supported the recognition of infraspecific taxa. In his treatment of $H$. panduriformis for the Malesian region, Van Borssum Waalkes (1966) noted Hochreutiner's (1900) infraspecific taxonomy, even though he did not give prominence to the appropriate variety, i.e. var. panduriformis, in his account.

Examination of herbarium specimens collected in Australia showed that there is considerably more variation within Australia than had been indicated by Hochreutiner (1900) and Van Borssum Waalkes (1966). Only some of the specimens can be assigned reasonably to var. australis. Others agree with the description of var. panduriformis as

1) Herbarium Bogoriense - Bidang Botani, PPB-LIPI, Jalan Raya Juanda 22, Bogor 16122, Indonesia; Present address: Museum of Biological Diversity, Ohio State University, 1315 Kinnear Road, Columbus, Ohio, 43212, USA.

2) Australian National Herbarium, CPBR, CSIRO Plant Industry, G.P. O. Box 1600, Canberra ACT 2601, Australia. 
given in Van Borssum Waalkes (1966, as H. panduriformis) and Sivarajan \& Pradeep (1996) and some specimens do not agree with any of the previously recognised varieties. The present revision of the taxonomy of the H. panduriformis complex in Australia was undertaken in order to resolve some of these uncertainties.

Across the range of the Australian material studied, there was much variation. The indumentum of vegetative organs in a single collection ranged from consisting of a single hair type (commonly short soft stellate hairs) to a mixture of four hair types (long coarse stellate hairs, long soft stellate hairs, short soft stellate and glandular hairs). Variation existed between collections in other features such as epicalyx lobe number, corolla size $(14-80 \mathrm{~mm}$ long) and style arm length $(0.2-6.5 \mathrm{~mm}$ long). Although there was much variation across the specimens studied, it was clear that variation within specimens was low. Furthermore, it was observed that there was correlation between geography and ecology for particular combinations of character states. We have concluded that the H. panduriformis complex within Australia comprises six species, five of which are endemic.

It might be argued that indumentum characters have been over-emphasised in the present study relative to other morphological features. However, hair types are important taxonomically in Malvaceae. Several recent authors, Rakshit \& Kundu (1970), Phuphathanaphong et al. (1989), Wilson (1993) and Wilson \& Craven (1995) used hair types in defining species. Van Borssum Waalkes (1966: 19) noted in his account of Malesian Malvaceae that every species can be characterised by its indumentum.

Until recently, $H$. panduriformis s.l. was thought to be the only species of $H$. sect. Trichospermum Hochr. that occurred in Australia. A second species, H. brennanii Craven \& Fryxell, has been described from the Northern Territory (Craven \& Fryxell, 1993). The two are distinguished by the following features: H. panduriformis s.l.: distal leaves on flowering shoots distinctly petiolate, leaves discolorous, corolla yellow; $H$. brennanii: distal leaves on flowering shoots sessile or subsessile, leaves concolorous, corolla pink. Their ecologies and distributions also differ with $H$. panduriformis s.l. commonly being a species of grassland to woodland communities on sandy to clay soils across northern Australia, while $H$. brennanii occurs on skeletal soils over sandstone. The latter species is presently known from a single locality in the Alligator Rivers region of the Northern Territory (Craven \& Fryxell, 1993); its distribution is given in Map 1 to permit comparison with that of the other Australian representatives of the section.

\title{
TAXONOMY
}

\section{Hibiscus apodus Juswara \& Craven, spec. nov. - Fig. 1; Map 1}

\begin{abstract}
Affinis $H$. panduriformi Burm.f. a qua ramulis sine trichomatibus longis grossisque, lamina folii breviore (21-58 mm longa, in $H$. panduriformi $21-186 \mathrm{~mm}$ longa), corollis $0.5-1$ plo longiore (in H. panduriformi 3.6-4.4plo longiore), sine pedunculo, ramulis styli longioribus (1.5-4 mm longis, in H. panduriformi $0.2-1 \mathrm{~mm}$ longis) differt. - Typus: Fryxell, Craven \& Stewart 4550 (holo CANB; iso BRI, MEL, NY, PERTH), Australia, Western Australia, 5 km NNE of Broome, 29 May 1985.
\end{abstract}

Shrubs to $2 \mathrm{~m}$ tall. Branchlets long and short soft stellate-hairy, with glandular hairs, indumentum obscuring the epidermis, long soft stellate hairs $1.5-2 \mathrm{~mm}$ long, short 
stellate hairs $0.2-0.3 \mathrm{~mm}$ long. Leaves with the petiole $20-50 \mathrm{~mm}$ long, blade short soft stellate-hairy, indumentum whitish to yellowish, in overall shape broadly elliptic, 3-lobed, 21-58 by 14-60 mm, 0.5-1 times as long as the petals of the subtended flower, margin serrate-dentate to crenate, base cordate, apex acute to rounded. Flowers without a peduncle, pedicel present. Epicalyx shorter than the calyx, short soft stellate-hairy, 7-segmented, segments shortly connate at the base, narrowly spathulate to linear-obovate, $7-15$ by $0.5-1 \mathrm{~mm}$. Calyx short soft stellate-hairy on the abaxial surface, campanulate, 12-18 mm long, lobes ovate, apex acute, 3-nerved. Petals yellow with red basal spots, short coarse stellate-hairy on the abaxial surface, glabrous on the adaxial surface, 35-57 by $14-43 \mathrm{~mm}$, rounded at the apex. Staminal column glabrous, 22-27 mm long, antheriferous throughout, filaments $0.5-1 \mathrm{~mm}$ long. Ovary hairy, style arms $1.5-4 \mathrm{~mm}$ long. Capsule hairy, $12-16$ by $8-10 \mathrm{~mm}$, beak $1 \mathrm{~mm}$ long. Seeds angular reniform, 2.5-3 mm long, concentrically ribbed, glabrous or short brownish stellate-hairy.

Distribution - Australia (coastal country in the northwest Kimberley region of Western Australia, especially frequent in the Dampier Peninsula area).

Habitat - Recorded as occurring in low woodland with Eucalyptus terminalis, Lysiphyllum cunninghamii and Atalaya hemiglauca on red sand soils; in the understorey of a regenerating Melaleuca acacioides thicket; on a coastal sand dune above high tide mark with Spinifex, Tribulus and mangrove nearby; on black soil; in cleared country on subsaline crumbly grey soil; and in grassland. This species has been recorded from

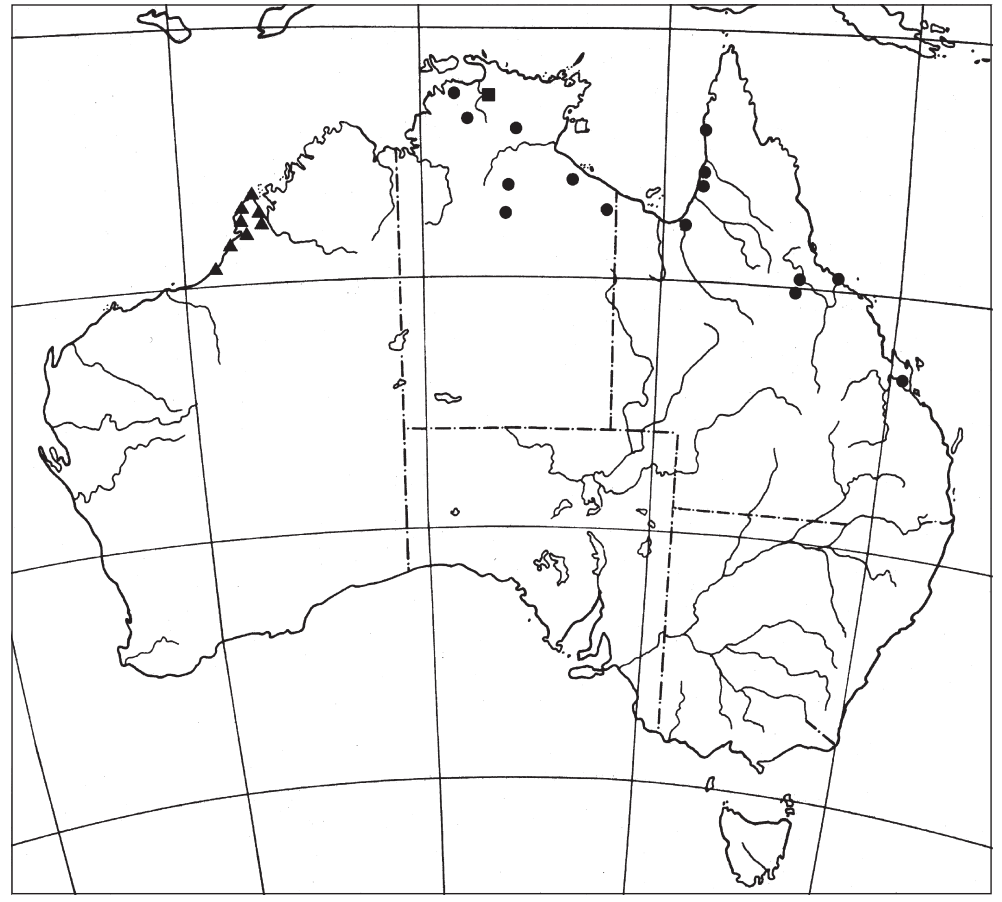

Map. 1. Distribution of Hibiscus apodus Juswara \& Craven (\), H. brennanii Craven \& Fryxell and H. panduriformis Burm.f. ( 


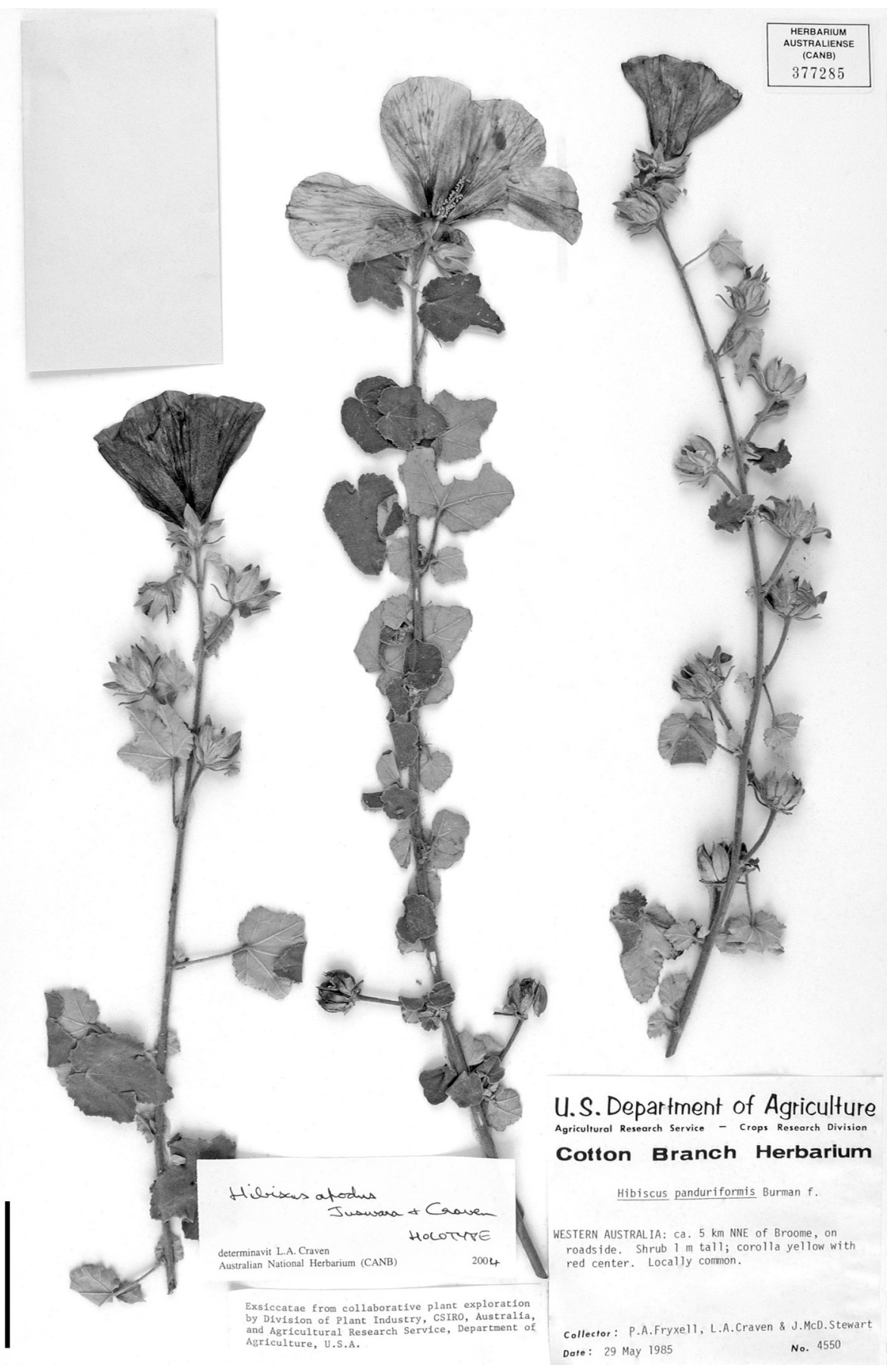

Fig. 1. Holotype of Hibiscus apodus Juswara \& Craven. - Scale bar $=5 \mathrm{~cm}$. 
quite diverse soil types and it is not unexpected that the communities that it has been recorded from are also diverse. Given that the geographic range of $H$. apodus is not especially large, it is of interest that it is found in such a range of habitats.

Notes - 1. Hibiscus apodus is the only Australian species of the complex that lacks a peduncle although, in common with the other species, it is pedicellate. This, together with the distinctive small leaves and large flowers, makes it easily distinguished from its relatives.

2. The specific epithet is derived from the Latin $a$, without, and podos, foot, in reference to the lack of a peduncle.

\section{Hibiscus austrinus Juswara \& Craven, stat. \& nom. nov. - Map 2a, b}

Based on: Hibiscus panduriformis var. australis Hochr. (1900) 96, replaced synonym. - Type: $n .97$ Herb. Boissier (holo G), Australia, Port Darwin (Palmerston), Dec. 1891.

Notes - 1. Unfortunately, the epithet 'australis' is preoccupied by H. australis (F. Muell.) Kuntze, and a new name is required for the plant at species level. The epithet 'austrinus' from the Latin austrinus, southern, is proposed above as the replacement.

2. Hibiscus austrinus is characterised by having dense branchlet indumentum composed of short or short and long stellate hairs and a 5-7-segmented epicalyx. Two varieties are recognised within the species.

\section{a. var. austrinus - Map 2a}

Subshrubs or shrubs to 1-2 m tall. Branchlets short soft stellate-hairy, without glandular hairs, indumentum obscuring the epidermis, short soft stellate hairs $0.3-0.5$ mm long. Leaves with petiole 20-124 mm long, blade short soft stellate-hairy, the indumentum yellowish or rarely whitish, in overall shape broadly elliptic, 3-lobed, 26-134 by $19-160 \mathrm{~mm}, 0.6-1.6$ times as long as the petals of the subtended flower, margin serrate-dentate to crenate, base cordate, apex acute. Flowers with the peduncle 2-34 mm long, pedicel present. Epicalyx shorter to longer than the calyx, short soft stellate-hairy, 5-7-segmented, segments shortly connate at base, spathulate to narrowly spathulate, $10-35$ by 1-4 mm. Calyx short soft stellate-hairy on the abaxial surface, campanulate, 15-34 mm long, lobes ovate, apex acute, 3-nerved. Petals yellow with red basal spots, short coarse stellate-hairy on the abaxial surface, glabrous on the adaxial surface, $38-80$ by $25-64 \mathrm{~mm}$, rounded at the apex. Staminal column glabrous, $13-80$ $\mathrm{mm}$ long, antheriferous throughout, filaments 1.5-2 mm long. Ovary hairy, style arms 1-6.5 mm long. Capsule hairy, $16-20$ by $12-15 \mathrm{~mm}$, the beak 1-2 mm long. Seeds angular reniform, 3-3.5 mm long, concentrically ribbed, glabrous or short brownish to yellowish stellate-hairy.

Distribution - Australia (from the Pilbara area north to the Kimberley region in Western Australia, and from the Victoria River area to the McArthur area in the Northern Territory).

Habitat - Recorded as occurring in grassy woodland on heavy grey loam on a flood plain; on black soil; on red loam by roadsides; on a riverine levee; on alluvial soils on calcrete with Eucalyptus patellaris; and on sandy loam soil. Although widespread and common, relatively little has been recorded of its ecology, but H. austrinus var. aus- 

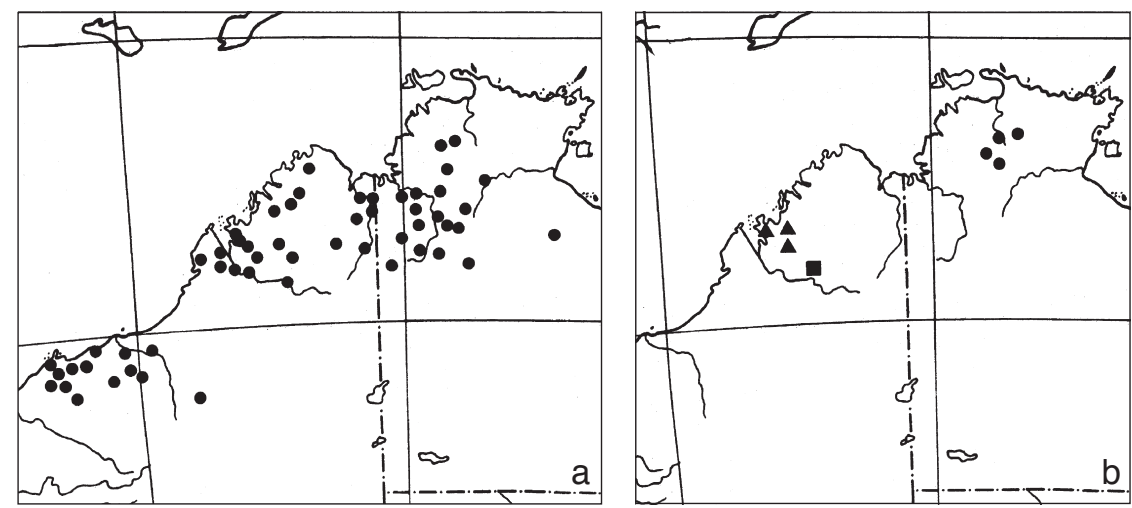

Map 2. Distribution of a. Hibiscus austrinus Juswara \& Craven var. austrinus; b. H. austrinus var.

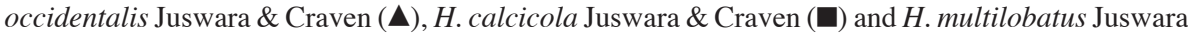
\& Craven (๑).

trinus seems to be tolerant of a wide range of soil types and appears to be a woodland taxon, although it was once recorded from a levee.

Note - The typical variety differs from var. occidentalis mainly in the lack of long soft stellate hairs in the former. Other differences such as the longer peduncle and style arms in var. austrinus (2-34 $\mathrm{mm}$ and 2-6.5 mm long, respectively, in var. austrinus and up to $3 \mathrm{~mm}$ and $1.5-3.5 \mathrm{~mm}$ long in var. occidentalis) may not be as significant given that var. occidentalis is known from only few collections (whereas var. austrinus is known from c. 125 collections).

b. var. occidentalis Juswara \& Craven, var. nov. - Fig. 2; Map 2b

A var. typica ramulis trichomatibus longis mollibusque (et trichomatibus brevibus mollibusque), pedunculo breviore ( $0-3 \mathrm{~mm}$ longo, in subsp. austrino $2-34 \mathrm{~mm}$ longo), ramulis styli interdum brevioribus (1.5-3.5 mm longis, in var. austrino 2-6.5 mm longis) differt. - Typus: Beauglehole 52782 (holo PERTH; iso DNA), Australia, Western Australia, junction of Stuart and Robinson Rivers, \pm 72 km NNW of Derby, 13 June 1976.

Subshrubs or shrubs to $0.6 \mathrm{~m}$ tall. Branchlets long and short soft stellate-hairy, without glandular hairs, indumentum obscuring the epidermis, long soft stellate hairs 2.2-3.4 $\mathrm{mm}$ long, short soft stellate hairs $0.3-0.5 \mathrm{~mm}$ long. Leaves with the petiole $20-45 \mathrm{~mm}$ long, blade short soft stellate-hairy, indumentum yellowish or rarely whitish, in overall shape broadly elliptic, 3-lobed, 31-93 by 21-72 mm, 1-1.4 times as long as the petals of the subtended flower, margin serrate-dentate to crenate, base cordate, apex acute. Flowers with the peduncle obsolete or up to $3 \mathrm{~mm}$ long, pedicel present. Epicalyx shorter than the calyx, short soft stellate-hairy, 6- or 7-segmented, segments shortly connate at base, spathulate, $10-16$ by $3.5-5 \mathrm{~mm}$. Calyx short soft stellate-hairy on the abaxial surface or rarely also long soft stellate-hairy, campanulate, 18-30 mm long, lobes ovate, apex acute, 3-nerved. Petals yellow with red basal spots, short coarse stellate-hairy on the abaxial surface, glabrous on the adaxial surface, $34-54$ by $24-42 \mathrm{~mm}$, rounded at the apex. Staminal column glabrous, 13-17 mm long, antheriferous throughout, filaments 


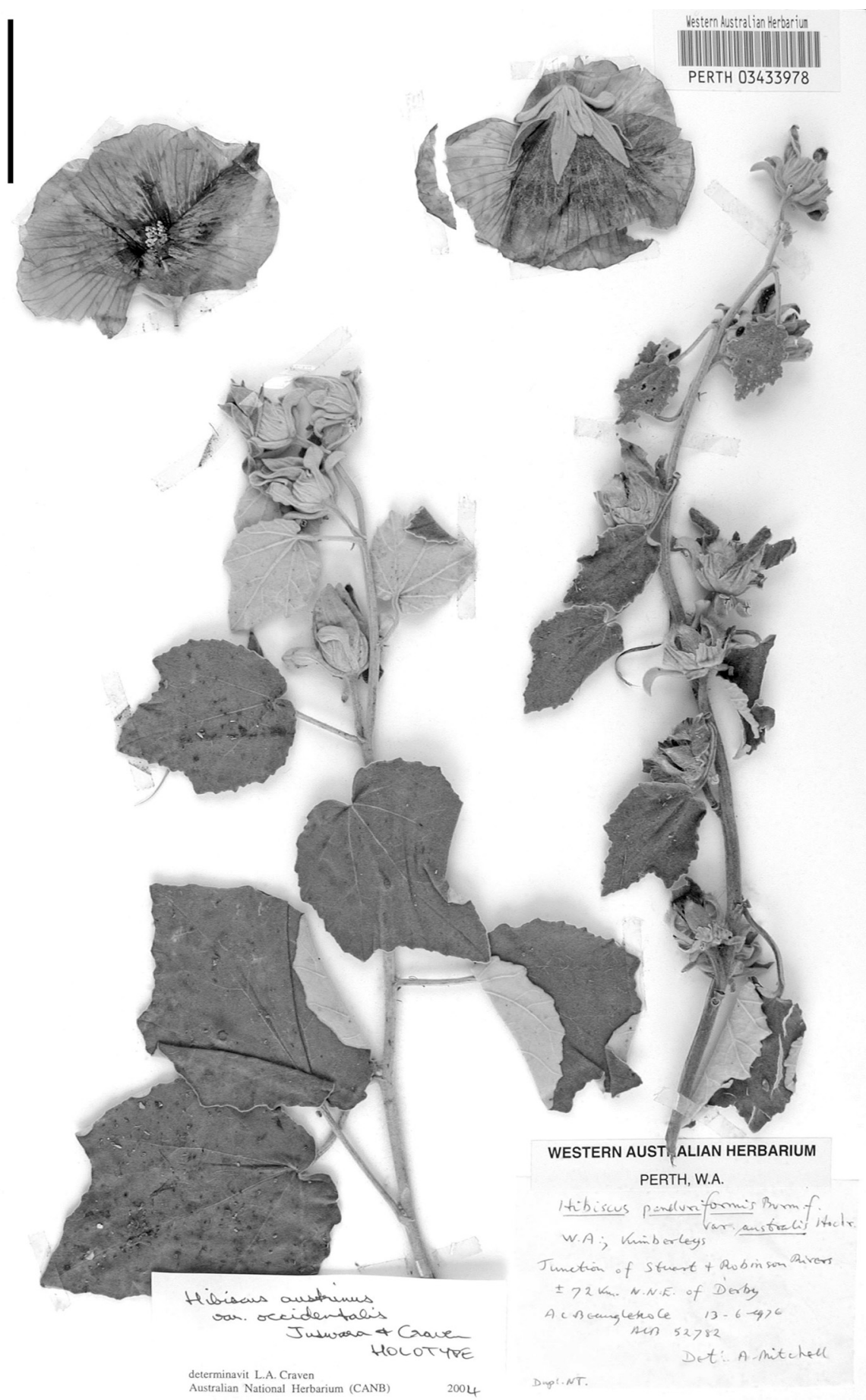

Fig. 2. Holotype of Hibiscus austrinus var. occidentalis Juswara \& Craven. - Scale bar $=5 \mathrm{~cm}$. 
0.7-1.7 mm long. Ovary hairy, style arms $1.5-3.5 \mathrm{~mm}$ long. Capsule hairy, $12-16$ by 12-15 mm, beak 1-2 mm long. Seeds angular reniform, 3-3.5 mm long, concentrically ribbed, glabrous or short brownish to yellowish stellate-hairy.

Distribution - Australia (the west Kimberley area in Western Australia).

Habitat - Recorded as occurring in open woodland with tussock grasses on black clay plain; on a river bank; and by a creek on a flood plain in heavy clay. Its ecology is generally similar to that of var. austrinus.

Notes -1 . This variety occurs within the general ranges of $H$. apodus and $H$. austrinus s.1. More research is needed to investigate the possible hybrid origin of the variety; the long soft stellate hairs may have been introgressed into $H$. austrinus in the northwestern part of its range from $H$. apodus which also grows in the western Kimberley area.

2. The varietal epithet is derived from the Latin occidentalis, west, in reference to the geographic distribution of the plant.

\title{
3. Hibiscus calcicola Juswara \& Craven, spec. nov. - Fig. 3; Map 2b
}

\begin{abstract}
Affinis $H$. panduriformi Burm. f. a qua ramulis sine trichomatibus glandularibus, trichomatibus longis grossisque plerumque longioribus (2-3.5 mm longis, in $H$. panduriformi $1.7-2.3 \mathrm{~mm}$ longis), lamina folii corollis 1.2 plo longiore (in H. panduriformi $3.6-4.4$ plo longiore), ramulis styli longioribus (2-3 mm longis, in H. panduriformi $0.2-1 \mathrm{~mm}$ longis) differt. - Typus: Tracey 13889 (holo BRI; iso DNA, PERTH, QRS), Australia, Western Australia, Geikie Gorge National Park, 22 May 1981.
\end{abstract}

Shrubs to $1.5 \mathrm{~m}$ tall. Branchlets long coarse and short soft stellate-hairy, without glandular hairs, indumentum not obscuring the epidermis, coarse stellate hairs 2-3.5 mm long, soft stellate hairs $0.3-0.5 \mathrm{~mm}$ long. Leaves with the petiole $15-32 \mathrm{~mm}$ long, blade short soft stellate-hairy, indumentum yellowish, in overall shape broadly elliptic, 3-lobed, 31-55 by $28-60 \mathrm{~mm}, 1.2$ times as long as the petals of the subtended flower, margin serrate-dentate to crenate, base cordate, apex acute. Flowers with the peduncle obsolete or up to $2 \mathrm{~mm}$ long, pedicel present. Epicalyx shorter than the calyx, short soft stellate-hairy, 6- or 7-segmented, segments shortly connate at the base, spathulate, $18-20$ by $3.5-4 \mathrm{~mm}$. Calyx short soft stellate-hairy on the abaxial surface, campanulate, 24-26 mm long, lobes ovate, the apex acute, 3-nerved. Petals yellow with red basal spots, short coarse stellate-hairy on the abaxial surface, glabrous on the adaxial surface, $34-36$ by $18-25 \mathrm{~mm}$, rounded at the apex. Staminal column glabrous, 16-18 $\mathrm{mm}$ long, antheriferous throughout, filaments $0.5-1 \mathrm{~mm}$ long. Ovary hairy, style arms 2-3 mm long. Capsule hairy, $15-20$ by $12-13 \mathrm{~mm}$, beak $1 \mathrm{~mm}$ long. Seeds angular reniform, 3-3.5 mm long, concentrically ribbed, short brownish to yellowish stellatehairy or rarely glabrous.

Distribution - Australia (Geikie Gorge in northern Western Australia).

Habitat - Recorded as occuring on red clay soils on limestone at the foot of limestone karst.

Notes -1 . The species is easily distinguished by the branchlet indumentum; its long coarse stellate hairs are especially noteworthy. The lack of appreciation of the diversity within a plant group often leads to that group being under collected and hence poorly known in herbaria; this may be one of the reasons for the paucity of collections of 


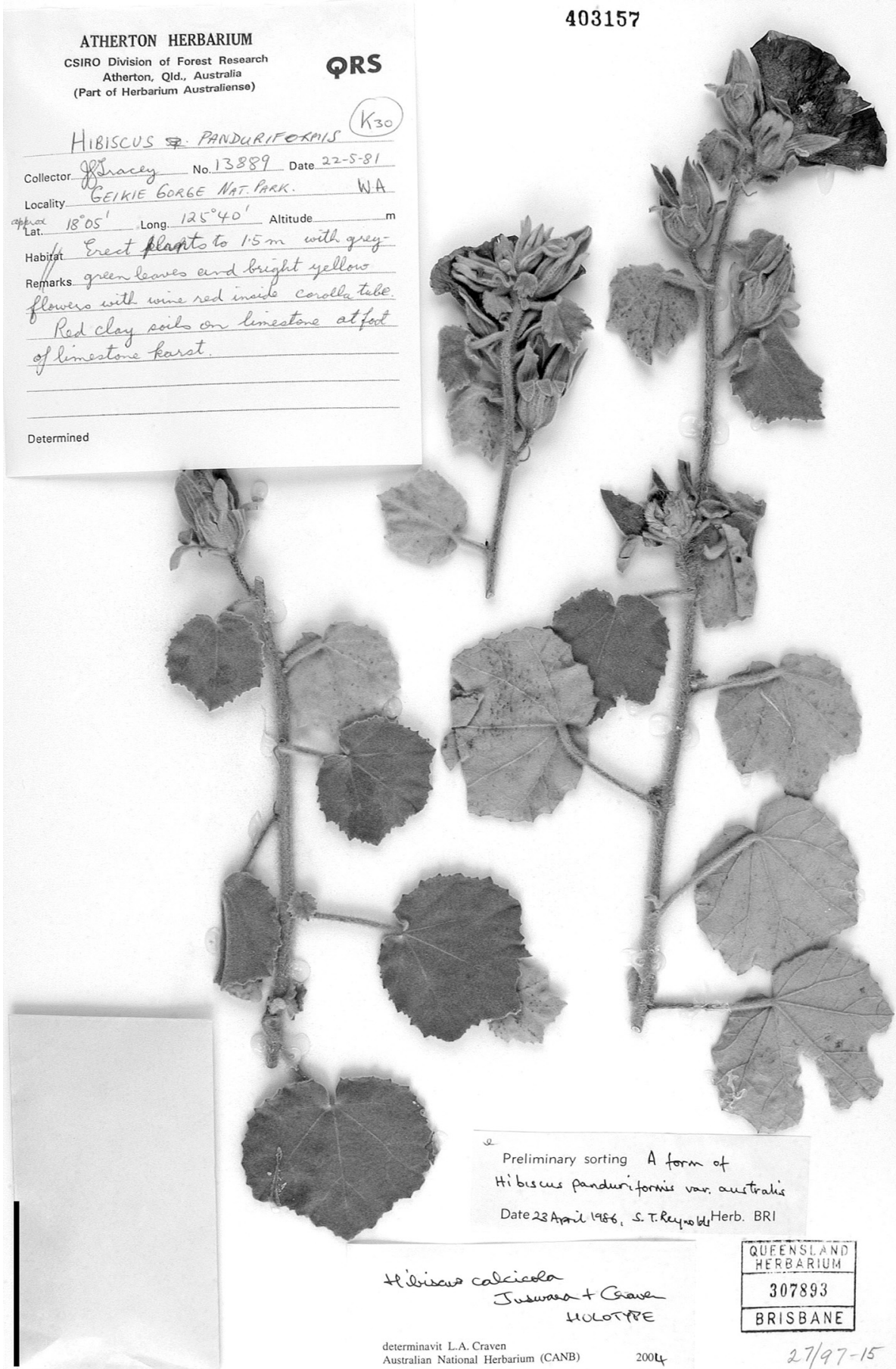

Fig. 3. Holotype of Hibiscus calcicola Juswara \& Craven. - Scale bar $=5 \mathrm{~cm}$. 
H. calcicola, presently known only from the type collection. Further specimen collections are needed to fully circumscribe the species and to define its range. In view of the lack of thorough investigation in northern Australia, the species could well occur in other areas of limestone in the Fitzroy River Basin.

2. The epithet 'calcicola' is proposed for this species because of its recorded association with limestone (calcium, hence limestone, and the Latin -cola, inhabitant or dweller).

4. Hibiscus fluvialis Juswara \& Craven, spec. nov. - Fig. 4; Map 3

Affinis H. panduriformi Burm.f. a qua ramulis sine trichomatibus mollibus vel glandularibus, trichomatibus longis grossisque brevioribus (1.3-1.6 mm longis, in $H$. panduriformi 1.7-2.3 mm longis), segmentis epicalycis 6-7 (in H. panduriformi segmentis 7-9) differt. - Typus: Fryxell \& Craven 4242 (holo CANB; iso AD, BISH, BRI, DNA, K, L, MEL, NY, PERTH, UC, US), Australia, Northern Territory, Daly River Mission, 22 May 1983.

Subshrubs or shrubs to $3 \mathrm{~m}$ tall. Branchlets long and short coarse stellate-hairy, without glandular hairs, indumentum not obscuring the epidermis, long coarse stellate hairs 1.3-1.6 mm long, short coarse stellate hairs $0.2-0.4 \mathrm{~mm}$ long. Leaves with the petiole 25-100 mm long, blade short soft stellate-hairy, indumentum whitish to yellowish, in overall shape broadly elliptic, 3-lobed, 36-106 by $28-95 \mathrm{~mm}, 2-4.7$ times as long as the petals of the subtended flower, margin serrate-dentate to crenate, base cordate, apex acute. Flowers with the peduncle obsolete or up to $5 \mathrm{~mm}$ long, pedicel present. Epicalyx shorter to longer than the calyx, short soft stellate-hairy, 6- or 7-segmented, segments shortly connate at base, narrowly spathulate to linear-obovate, 9-20 by 1-2 $\mathrm{mm}$. Calyx short soft stellate-hairy on the abaxial surface, campanulate, 14-20 mm long, lobes ovate, apex acute, 3-nerved. Petals yellow with red basal spots, short coarse stellate-hairy on the abaxial surface, glabrous on the adaxial surface, 15-24 by 8-12 $\mathrm{mm}$, rounded at the apex. Staminal column glabrous, 10-17 mm long, antheriferous throughout, filaments $0.2-0.4 \mathrm{~mm}$ long. Ovary hairy, style arms $0.4-1 \mathrm{~mm}$ long. Capsule hairy, $14-20$ by $10-12 \mathrm{~mm}$, beak 1-2 mm long. Seeds angular reniform, 2-3 mm long, concentrically ribbed, glabrous or short brownish stellate-hairy.

Distribution - Australia (on the Fitzroy River at Noonkanbah in Western Australia, from the Victoria River eastwards to the McArthur River area in the Northern Territory, and in the Gregory River area in Queensland).

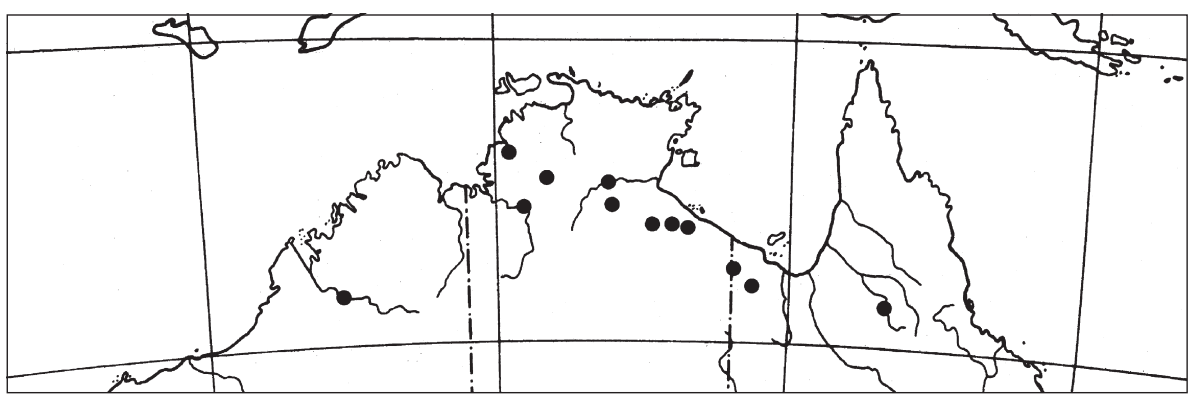

Map. 3. Distribution of Hibiscus fluvialis Juswara \& Craven. 


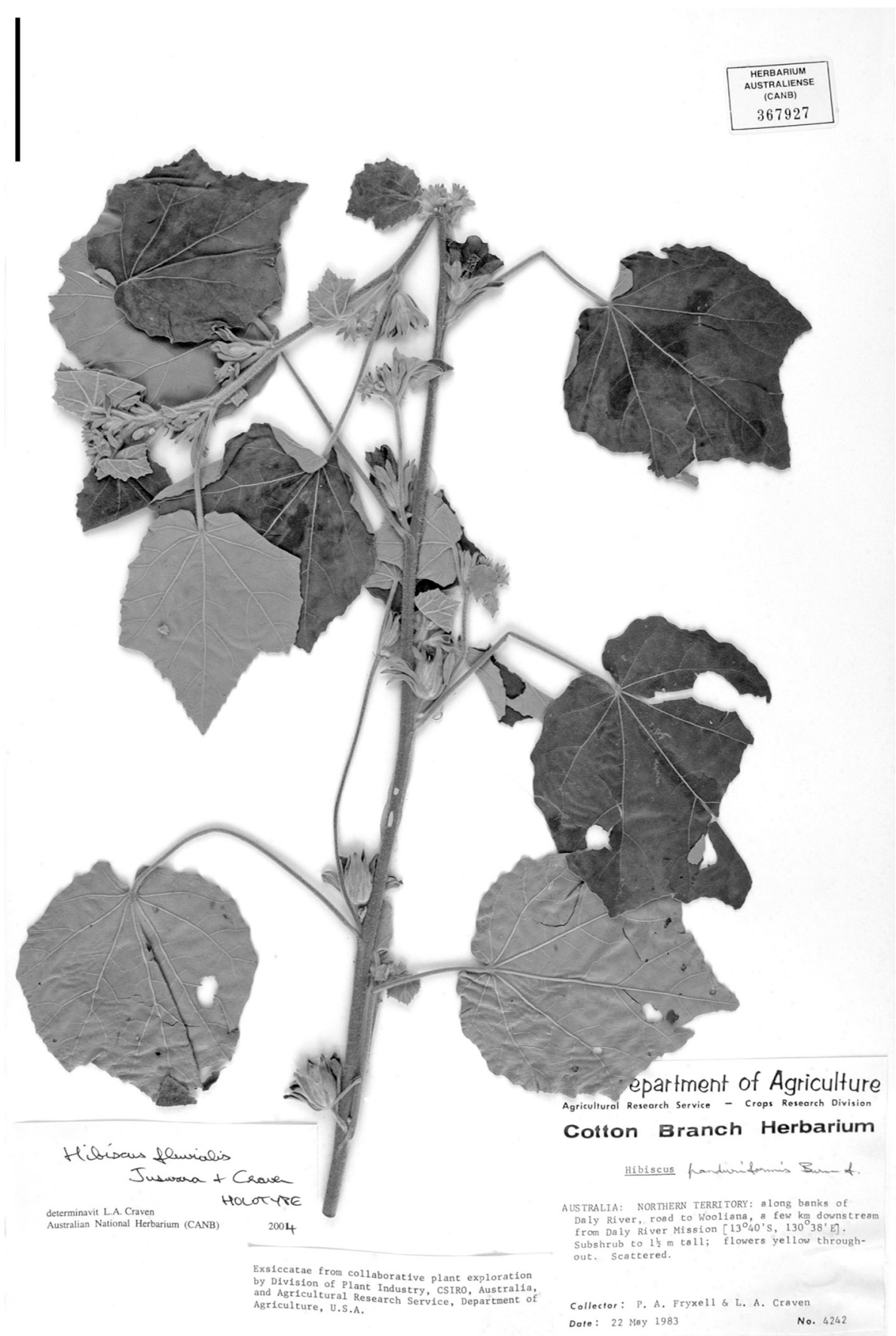

Fig. 4. Holotype of Hibiscus fluvialis Juswara \& Craven. - Scale bar $=5 \mathrm{~cm}$. 
Habitat - Recorded as occurring in riverine habitats such as riparian closed forest; on flat sandy area in open forest of Melaleuca leucadendra; in a sandy river bed; in sand above river under Casuarina; and with Casuarina cunninghamiana, Syzygium forte and Terminalia microcarpa. Interestingly, the species appears to be associated always with rivers and seems usually to occur on sandy substrates.

Notes -1 . Characteristic features of this species are the small flowers (corolla 15-24 mm long), lack of glandular hairs on the branchlets and the short style arms (0.2-1 mm long).

2. The specific epithet of $H$. fluvialis is derived from the Latin fluvialis, stream, in reference to the riverine habitat in which this species typically occurs.

\title{
5. Hibiscus multilobatus Juswara \& Craven, spec. nov. - Fig. 5; Map 2b
}

\begin{abstract}
Affinis $H$. panduriformi Burm.f. a qua ramulis sine trichomatibus longis grossisque vel glandularibus, lamina folii corollis $0.8-1$ plo longiore (in H. panduriformi 3.6-4.4plo longiore), pedunculo longiore (7-48 $\mathrm{mm}$ longo, in $H$. panduriformi $0-6 \mathrm{~mm}$ longo), segmentis epicalycis 12-19 (in H. panduriformi 7-9), corolla longiore (45-74 mm lon$\mathrm{ga}$, in $H$. panduriformi $15-37 \mathrm{~mm}$ longa), ramulis styli longioribus (3-5 $\mathrm{mm}$ longis, in H. panduriformi 0.2-1 mm longis) differt. - Typus: Slee, Craven, Dunlop \& Munns 2784 (holo CANB; iso DNA, MEL), Australia, Northern Territory, Kakadu National Park to Koolpin Gorge road, c. 6 km due E of El Sharana, 23 April 1990.
\end{abstract}

Subshrubs or shrubs to $3 \mathrm{~m}$ tall. Branchlets short soft stellate-hairy, without glandular hairs, indumentum obscuring the epidermis, short soft stellate hairs $0.8-1.2 \mathrm{~mm}$ long. Leaves with the petiole 20-60 mm long, blade short soft stellate-hairy, indumentum yellowish, in overall shape broadly elliptic, 3-lobed, $48-75$ by $45-73 \mathrm{~mm}, 0.8-1$ times as long as the petals of the subtended flower, margin serrate-dentate to crenate, base cordate, apex acute to rounded. Flowers with the peduncle 7-48 $\mathrm{mm}$ long, pedicel present. Epicalyx shorter than the calyx, short soft stellate-hairy, 12-19-segmented, segments shortly connate at base, narrowly spathulate to spathulate, $10-21$ by 1-3 $\mathrm{mm}$. Calyx short soft stellate-hairy on abaxial surface, campanulate, 20-28 mm long, lobes ovate, apex acute, 3-nerved. Petals yellow with red basal spots, short coarse stellate-hairy on the abaxial surface, glabrous on the adaxial surface, $45-74$ by $35-38$ $\mathrm{mm}$, rounded at the apex. Staminal column glabrous, 15-26 mm long, antheriferous throughout, filaments $0.5-1 \mathrm{~mm}$ long. Ovary hairy, style arms 3-5 mm long. Capsule hairy, $18-25$ by $14-19 \mathrm{~mm}$, beak 1-2 mm long. Seeds angular reniform, 3-3.5 mm long, concentrically ribbed, glabrous or short brownish to yellowish stellate-hairy.

Distribution - Australia (the Katherine-upper South Alligator River area in the Northern Territory).

Habitat - Recorded as occurring in tall grassland with scattered trees of Eucalyptus koolpinensis in low lying area on red clay; on alluvial soil with Sorghum spp. near a floodway; on a lightly timbered plain on heavy grey stony pedocalcis soil; in partially cleared savannah on low ground; in an alluvial depression fringed with Eucalyptus oligantha and dominated by Sorghum australiense, Chrysopogon latifolius, other grasses and herbs; and on a sandy channel bank. The available specimen label data indicates that $H$. multilobatus occurs in low-lying situations that probably are seasonally inundated. 


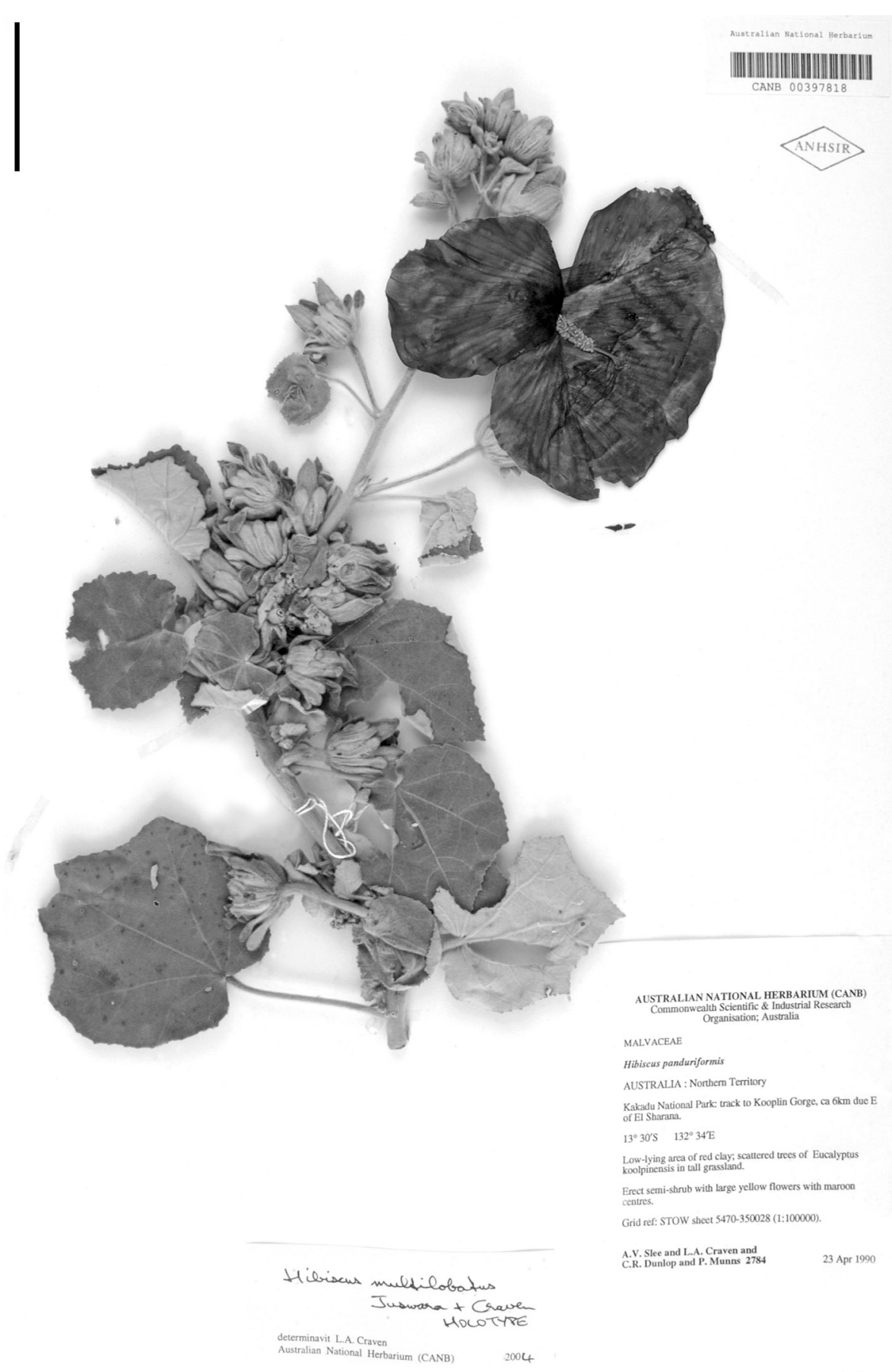

Fig. 5. Holotype of Hibiscus multilobatus Juswara \& Craven. - Scale bar $=5 \mathrm{~cm}$. 
Notes -1 . This species is easy to recognise by the numerous epicalyx segments (12-19) and the longish soft stellate hairs of the branchlets $(0.8-1.2 \mathrm{~mm}$ long).

2. The specific epithet of this species is derived from the Latin multus, many, and lobus, lobe, in reference to the numerous epicalyx segments.

\section{Hibiscus panduriformis Burm.f. - Map 1}

Hibiscus panduriformis Burm.f. (1768) 151, t. 47, f. 2. - Hibiscus tubulosus Cav. (1787) 161, t. 68, f. 2, nom. illeg. - Abelmoschus panduriformis (Burm.f.) Hassk. (1843) 134. - Hibiscus panduriformis var. tubulosus (Cav.) Hochr. (1900) 96, nom. illeg. - Type: A specimen has not been located and the name is typified by the illustration that forms part of the protologue.

Hibiscus velutinus DC. (1824) 452. - Type: Riedlé s.n. (holo n.v., photograph v. G-DC), Timor.

Subshrubs or shrubs to $3 \mathrm{~m}$ tall. Branchlets long coarse and soft stellate-hairy and short soft stellate-hairy, with glandular hairs, indumentum not obscuring the epidermis, long coarse stellate hairs $1.7-2.3 \mathrm{~mm}$ long, long soft stellate hairs $2.5-4 \mathrm{~mm}$, short soft stellate hairs $0.3-0.4 \mathrm{~mm}$ long. Leaves with the petiole $20-180 \mathrm{~mm}$ long, blade short soft stellate-hairy, indumentum whitish to yellowish, in overall shape broadly elliptic, 3-lobed, 21-186 by 19-151 mm, 3.6-4.4 times as long as the petals of the subtended flower, margin serrate-dentate to crenate, base cordate, apex acute. Flowers with the peduncle obsolete or up to $6 \mathrm{~mm}$ long, pedicel present. Epicalyx shorter than the calyx, short soft stellate-hairy, 7-9-segmented, segments shortly connate at the base, narrowly spathulate to linear-obovate, $5-12$ by $1-2 \mathrm{~mm}$. Calyx short soft stellate-hairy on the abaxial surface, campanulate, 10-18 mm long, lobes ovate, apex acute, 3-nerved. Petals yellow with red basal spots, short coarse stellate-hairy on the abaxial surface, glabrous on the adaxial surface, $15-37$ by $8-10 \mathrm{~mm}$, rounded at the apex. Staminal column glabrous, $8-18 \mathrm{~mm}$ long, antheriferous throughout, filaments $0.6-1 \mathrm{~mm}$ long. Ovary hairy, style arms $0.2-1 \mathrm{~mm}$ long. Capsule hairy, $10-16$ by $8-12 \mathrm{~mm}$, beak $1-2$ $\mathrm{mm}$ long. Seeds angular reniform, 2-3 mm long, concentrically ribbed, glabrous or short brownish to yellowish stellate-hairy.

Distribution - Australia (scattered in the Darwin, Newcastle Waters and McArthur River areas of the Northern Territory and scattered in the Gulf of Carpentaria, Charters Towers-Townsville, and Rockhampton areas of Queensland). As mentioned below, the species also occurs in Africa, Asia and Malesia.

Habitat - Recorded as occuring on black basaltic soil, in swampy Eucalyptus woodland on black soil; in a floodway with Acacia, Iseilema and Eragrostis; and on a river flood plain. The ecology of $H$. panduriformis is much less variable than that of $H$. apodus and $H$. austrinus. The black soil country in which the species occurs typically is poorly drained during the monsoon season although it becomes very dry during the dry season. These habitats are generally consistent with the ecology recorded for H. panduriformis by Van Borssum Waalkes (1966).

Notes -1 . No authentic specimens of $H$. panduriformis are known to exist (Van Borssum Waalkes, 1966; Sivarajan \& Pradeep, 1996) but the name can be typified by the plate in the protologue. The locality from which Burman's specimens came is not precisely known. Merrill (1921) indicated that they may have come from India or Java.

2. The holotype of the name $H$. velutinus, a species included in $H$. panduriformis by Van Borssum Waalkes (1966), is lodged at G-DC and cannot be borrowed but an 
image of the specimen was obtained. The species appears to be placed correctly with H. panduriformis.

3. So that the extent of variation across the $H$. panduriformis s.l. complex could be assessed, representative specimens from Africa, Madagascar, India and Indonesia were borrowed from $\mathrm{G}$ and K. Specimens from India and Indonesia (including Timor) were consistent with Burman's plate of $H$. panduriformis and the interpretation of this species adopted by Van Borssum Waalkes (1966) and Sivarajan \& Pradeep (1996). Some of the African specimens also belong to this taxon indicating that $H$.panduriformis s.s. is widespread. Other specimens from Africa, in our opinion, are not conspecific with $H$. panduriformis s. s. and probably equate to a taxon established for African plants by Hochreutiner (1900), H. panduriformis var. senegalensis Hochr. (= H. senegalensis Guill. \& Perr. nom. illeg., non Cav.), the type which we have not seen. It thus appears that there may be at least two specific level entities of the complex in Africa, i.e. $H$. panduriformis s.s. and a species requiring a new name in place of the illegitimate name $H$. senegalensis Guill. \& Perr.

4. Two of the Australian species have glandular hairs, $H$. panduriformis and $H$. apodus. For recognition purposes, the glandular hairs are a good identification feature and these, together with the leaf blade being 3.6-4.4 times as long as the corolla and the short style arms (0.2-1 mm long), adequately characterise $H$. panduriformis.

5. A collection in MEL (Palmer s.n., Queensland, Mitchell River, 1882) may represent this species. The material lacks glandular hairs as far as we can ascertain but, despite lacking adequate foliage, has the general facies of $H$. panduriformis. On the sheet also is a sample of bark fibre and the specimen label in the handwriting of F. Mueller bears the text "Fibre used by the natives of N. Queensl.".

\section{KEY TO THE SPECIES OF HIBISCUS SECTION TRICHOSPERMUM IN AUSTRALIA}

1a. Distal leaves on flowering shoots sessile or subsessile, leaves concolorous, flowers

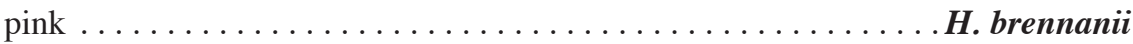

b. Distal leaves on flowering shoots distinctly petiolate, leaves discolorous, flowers

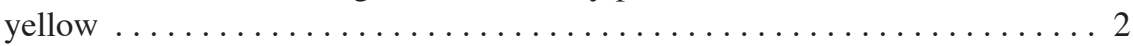

2a. Branchlets with glandular hairs (in addition to stellate hairs) $\ldots \ldots \ldots \ldots \ldots 3$

b. Branchlets without glandular hairs (only stellate hairs present) . . . . . . . . 4

3a. Petals 35-37 mm long; leaf blade 0.5-1 times as long as the petals, 21-58 $\mathrm{mm}$ long; peduncle absent; style arms $1.5-4 \mathrm{~mm}$ long . . . . . . . 1. H. apodus

b. Petals 15-37 mm long; leaf blade 3.6-4.4 times as long as the petals, $21-186 \mathrm{~mm}$ long; peduncle obsolete or up to $6 \mathrm{~mm}$ long; style arms $0.2-1 \mathrm{~mm}$ long . . . . . .

6. H. panduriformis

4a. Petals 15-24 mm long; leaf blade 2-4.7 times as long as the petals; style arms $0.4-1 \mathrm{~mm}$ long. . . . . . . . . . . . . fluvialis

b. Petals $34-80 \mathrm{~mm}$ long; leaf blade $0.6-1.6$ times as long as the petals; style arms

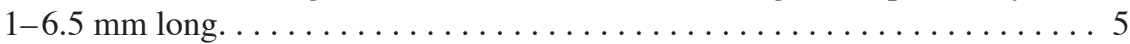

5a. Epicalyx 5-7-segmented; branchlets with the short soft stellate hairs $0.3-0.5 \mathrm{~mm}$ long (long coarse or long soft stellate hairs may also be present) $\ldots \ldots \ldots 6$ 
b. Epicalyx 12-19-segmented; branchlets with the short soft stellate hairs $0.8-1.2$ $\mathrm{mm}$ long (long coarse or long soft stellate hairs are absent) . 5. H. multilobatus

6a. Branchlet indumentum obscuring the epidermis, the indumentum composed of soft stellate hairs (whether these long and short or only short) $\ldots \ldots \ldots \ldots \ldots$

b. Branchlet indumentum not obscuring the epidermis, the indumentum composed of

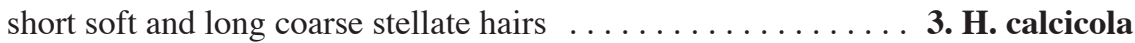

7a. Branchlet indumentum composed of short soft stellate hairs; peduncle 2-34 mm long; style arms $1-6.5 \mathrm{~mm}$ long . . . . . . . 2a. H. austrinus var. austrinus

b. Branchlet indumentum composed of short and long stellate hairs; peduncle up to $3 \mathrm{~mm}$ long; style arms $1.5-3.5 \mathrm{~mm}$ long. . . 2 2b. H. austrinus var. occidentalis

\section{ACKNOWLEDGEMENTS}

There are many people who have contributed to this project in the provision of materials, information, discussion, assistance, hospitality, companionship in the field, etc., and to all we are greatly appreciative. Special thanks are due to Greg Chandler, John Clarkson, John Connors, Mike Crisp, Ross Cunningham, Christine Donnelly, Clyde Dunlop, Paul Fryxell, Penny Gullan, Helen Hadobas, Pennie Hohnen, Joan Graham, Kevin Kenneally, Andrew Mitchell (of Meekatharra, Broome \& Darwin), Paul Munns, Jo Palmer, Bernard Pfeil, Andrew Slee, Mac Stewart, Judy West and Frank Zich. Paul Fryxell is thanked for his helpful comments on the manuscript. The directors and/or curators of the following herbaria are thanked for the opportunity to study specimens in their care: AD, BRI, CANB, DNA, G, K, MEL, NSW, PERTH and QRS.

\section{REFERENCES}

Burman, N.L. 1768. Hibiscus panduriformis. In: Flora Indica: 151, t. 47, f. 2. Haak, Leiden; Schreuder, Amsterdam.

Cavanilles, A.J. 1787. Hibiscus tubulosus. In: Monadelphiae classis dissertationes decem, Diss. 3: Tertia dissertatio botanico: 161, t. 68, f. 2. Didot, Paris.

Craven, L.A. \& P.A. Fryxell. 1993. Additions to Australian Hibiscus (Malvaceae): a new species and a new record. The Beagle 10: 1-6.

De Candolle, A.P. 1824. Hibiscus. In: Prodromus systematis naturalis regni vegetabilis 1: 446-455. Treuttel \& Würtz, Paris, Strasbourg, London.

Exell, A.W. 1961. Hibiscus. In: A.W. Exell \& H. Wild, Flora Zambesiaca, vol. 1: 434-472. Crown Agents for Overseas Governments and Administrations, London.

Hasskarl, J.K. 1843. Tijdsch. Natuurl. Gesch. Physiol. 10: 134.

Hochreutiner, B.P.G. 1900. Révision du genre Hibiscus. Annuaire Conserv. Jard. Bot. Genève 4: 23-191.

Merrill, E.D. 1921. A review of the new species of plants proposed by N.L. Burman in his Flora Indica. Philipp. J. Sci. 19: 329-388.

Phuphathanaphong, L., P. Siriruksa \& G. Nuvongsri. 1989. The genus Hibiscus in Thailand. Thai Forest Bull., Bot. 18: 43-79.

Rakshit, S.C. \& B.C. Kundu. 1970. Revision of the Indian species of Hibiscus. Bull. Bot. Surv. India 12: 151-175.

Sivarajan, V.V. \& A.K. Pradeep. 1996. Malvaceae of southern Peninsular India: a taxonomic monograph. Daya Publishing House, New Delhi.

Stafleu, F.A. 1971. Linnaeus and the Linnaeans: the spreading of their ideas in systematic botany, 1735-1789. Oosthoek, Utrecht.

Van Borssum Waalkes, J. 1966. Malesian Malvaceae revised. Blumea 14: 1-213.

Wilson, F.D. 1993. Hibiscus section Furcaria (Malvaceae) in islands of the Pacific Basin. Brittonia 45: $275-285$. 
Wilson, F.D. \& L.A. Craven. 1995. Two new species of Hibiscus section Furcaria DC. (Malvaceae) from northern Queensland. Austrobaileya 4: 439-447.

\section{INDEX TO NUMBERED EXSICCATAE}

The number following the colon is the number of the taxon in the taxonomic section above.

Adams 886: 5 - Allan 592: 1 - Aplin 4690: 2a; 4830: 2a; 4934: 2a; 5474: 2a; 5528: 2a; 5074: 2b - Aplin, Cranfield \& Wheeler 83: 1; 409: 2a.

Barker 2028: 2a - Barker \& Scarlett 534: 2a - Barnsley 1548: 2a - Barrett 190: 2a - Beard 2839: 2a; 2935: 2a; 4044: 1 - Beauglehole 51271: 2a; 51738: 2a; 52782: 2b (T); 53555: 2a; 53559: 2a; 53650: 2a; 54345: 2a; 54571: 2a; 54819: 4; 54859: 4; 54981: 4; 55041: 4 - Beauglehole 58289 \& Errey 1989: 2a - Blake 12358: 4; 17456: 5 - Blockley 387: 2a; 853: 2b - Booth 1368: 2a - Brass 150: 6 - Brooker 2068: 2a - Burbidge 1083: 2a; 1288: 1; 1352: 1; 1363: 1; 5038: 5; 5091: 5; 5821: 2a - Byrnes 352: 2a; 402: $2 \mathrm{a}$.

Carr 2714 \& Beauglehole 46493: 2a; 4356 \& 48134: 1; $4407 \&$ 48185: 1; 4566 \& 48344: $2 \mathrm{a}$ - Carter 465: 1 - Casson 73: 2a - Chippendale 2166: 2a; 2343: 2a; 2365: 2a; 4510: 2a; 5769: 2a; 6828: 2a - Clark 2018: 4; 612: 2a - Clarke 2154: 6 - Clarkson \& Neldner 9507: 6 - Cowie \& Booth 6256: $2 \mathrm{a}$ - Cowie \& Egan 4612: 2a - Craig 408: 1 - Craven 8453: 1; 4064: 4 - Craven, Grace \& Second 8492: 4; 8496: 2a; 8506: 6; 8518: 6 - Craven \& Stewart 9302: 2a.

Dalliston 443: 6 - Demarz 2448: 2a - Donner 6159: 2a - Dunlop 1974: 2a; 3187: 5; 3592: 4 - Dunlop \& Munns 8621: 5 - Dorney 41: 6 .

Eddy 40: 2a - Edinger 413: 2b - Egan 537: 2a; 4053: 2a - Egan \& Leach 2666: 4 - Eichler 22340: $2 \mathrm{a}$.

Finlayson 62: 5 - Forbes 2386: 1 - Foulkes 8: 1 - Fryxell 3853: 1; 5223: 2a - Fryxell \& Craven 4073: 2a; 4211: 2a; 4242: 4 (T) - Fryxell, Craven \& Stewart 4423: 2a; 4547: 2a; 4550: 1 (T); 4559: $2 \mathrm{a}$.

Garden 3262: 2a - Gardner 1050: 6; 1550: 6; 3099: 2a; 3100: 2a; 6285: 2a; 7103: 4; 8126: 2a; 10002: 2a; 10042: 2a; 12392: 2a - George 1093: 2a; 1109: 2a; 10863: 2a - Goble-Garratt 543: 2a.

Henshall 1917: 2a; 3532: 2a - Hutchinson 6: 1.

Jacobs 1241: 6 - Johnson 5089: 2a.

Kenneally 7641: 1 ; 9411: 1 - Kimbel 10: 2a.

Langfield 12: 2a - Latz 9352: 6; 10239: 4; 90: 2a - Lazarides 7996: 5 - Leach 4083: 6 - Leach \& Dunlop 2387: 2a - Leutert 13: 2a.

MacGillivray 2183: 2a - Mackenzie 690312-26: 2a - Maconochie 309: 2a - McCarthy 229: 2a - McGlasson 38: 6 - McKey 60: 4 - Menkhorst 893: 2a - Michell \& Calliss 777: 2a — Mitchell 298: 2a; 874: 2a; 2010: 1; 2564: 2a; 2631: 2a - Must 1267: 2a; 1569: 2a.

Neldner \& Clarkson 2889: 6 - Newbey 9992: 2a; 10564: 2a - Norris 886: $2 \mathrm{a}$.

Ollerenshaw 42: 2a; 1577: 2a - Ollerenshaw \& Kratzing 1362: 4.

Parker 257: 2a - Paton 91: 2a - Perry 1793: 4; 2071: 2a; 2179: 2a - Perry \& Lazarides 2580: 2a; 2788: 5; 2833A: 2a - Pfeiffer 1: 2a - Powes 720: 2a - Pullen 10604: 5; 10707: 2a - Purdie 3260: $2 \mathrm{a}$

Rankin 1306: 2a; 2380: 6; 2457: 6 - Rice 2323: 4 - Richards 1: 2a - Richardson 26: 2a - Rodd 2840: 2a - Royce 3265: 2a; 6824: 1; 6969: 2a - Russell-Smith \& Lucas 6046: 4; 7747: 2a; 7841: 2a.

Sand BR5: 1 - Scrymgeour 1709: 2a - Short \& Dunlop 4583: 4 - Sivertsen 928: 2a - Slee, Craven, Dunlop \& Munns 2784: 5 (T) - Smith 374: 5; 1108: 2a; 3990: 2a - Stokes 1: 2a - Strong 872: 2a - Symon 5223: 2a; 5320: 2a; 5357: 1; 5405: 2a; 6941: 2a; 10301: 2a.

Telford \& Butler 5967: 2a; 6278: 2a - Tepper 48: 2a - Thompson \& Sharpe 18: 6 - Thomson 1885: 4 - Tracey 13875: 1; 13889: 3 (T); 13893: 2a; 13896: 2a.

Walter 2: 2a - Weston 12469: 2a; 12753: 2a - Wightman \& Jackson 6708: 2a - Williams \& Wightman 72: 2a - Wilson 374: 5; 959: 2a; 1110: 2a; 12525: 1 - Wyatt 8: 6 .

Yeates 26: 2a.

Zich 153: 1; 176: 2a. 